\title{
Epididymal Leiomyoadenomatoid Tumour: A Rare Case Report and Literature Review
}

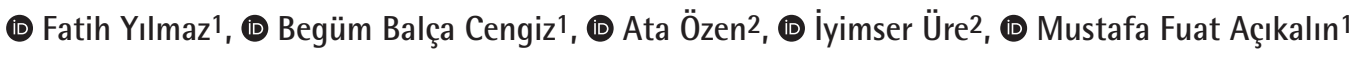 \\ 1Eskişehir Osmangazi University Faculty of Medicine, Department of Pathology, Eskişehir, Turkiye \\ 2Eskişehir Osmangazi University Faculty of Medicine, Department of Urology, Eskişehir, Turkiye
}

\begin{abstract}
Adenomatoid tumours are benign neoplasms of mesothelial origin that most often occur in the epididymis in men and the uterus or fallopian tubes in women. When the stromal smooth muscle component is prominent, the term leiomyoadenomatoid tumour is recommended. To date, only 10 cases of epididymal leiomyoadenomatoid tumour have been reported. In some cases, coagulation necrosis associated with worrisome regenerative changes can occur and leads to an increase in diagnostic pitfalls such as malignant neoplastic processes. Pathologists should be aware of this entity to avoid misdiagnosis. Herein, we present the eleventh case of epididymal leiomyoadenomatoid tumour in a 59-year-old man.
\end{abstract}

Keywords: Adenomatoid tumour, smooth muscle, leiomyoadenomatoid tumour, epididymis

\section{Introduction}

Adenomatoid tumours (ATs) are benign neoplasms of mesothelial origin that predominantly occur in the genital tract of men and women (1). They most often occur in the epididymis in men and the uterus or fallopian tubes in women (1). ATs are characterised by a minimally infiltrative proliferation consisting of tubular and gland-like spaces lined by flattened layer of neoplastic cells. Their collagenous stroma is often hyalinised, but admixed smooth muscle may also be present. The term leiomyoadenomatoid tumour (LAT) is recommended when the smooth muscle component is prominent (2). Our literature review revealed 27 cases of LAT located in the epididymis and uterus or adnexa. Only ten of them were located in the epididymis (3-11). Herein, we present a rare case of epididymal LAT in a 59-year-old man and review the literature.

\section{Case Report}

A 59-year-old man presented to our clinic for testicular pain of 2 weeks duration. On physical examination, a mass of approximately $2 \mathrm{~cm}$ was found in his right scrotum. Doppler ultrasonography showed an intrascrotal solid lesion $19 \times 18 \mathrm{~mm}$ in size within the right scrotal cavity, which had parenchymal microcalcifications. The lesion was compressing the nearby parenchyma of the testis and exhibited peripheral vascularity. Ultrasonographic examination showed that the mass was extratesticular and intrascrotal. Tumour markers were normal (alpha-fetoprotein, $2.2 \mathrm{IU} / \mathrm{mL}$; human chorionic gonadotropin, $<0.200 \mathrm{MIU} / \mathrm{mL}$; lactate dehydrogenase, $220 \mathrm{U} / \mathrm{L}$ ). Thoracal and abdominopelvic computed tomography did not detect metastatic lesion preoperatively. The patient had hypertension and had undergone aortic surgery for aortic aneurysm, transurethral resection of the prostate and total thyroidectomy. Inguinal orchiectomy was performed since mass margins could not be clearly distinguished from the normal testicular tissue.

On macroscopic examination, a solid mass arising from the tail of the epididymis was found. The size of the mass was $1.7 \times 1.5 \times 1.3$ $\mathrm{cm}$. It was pushing toward the testicular tissue. The cut surface showed a greyish white whorled pattern. Other parenchymal areas were normal.

Microscopically, the lesion was well-circumscribed and had two components. The first component consisted of bundles of uniform, fusiform smooth muscle cells in a fascicular arrangement. Smooth muscle bundles were separated by the second component composed of cords, small nests or tubularlike structures lined by plump epithelioid cells with round

Correspondence: Mustafa Fuat Açıkalın MD, Eskişehir Osmangazi University Faculty of Medicine, Department of Pathology, Eskişehir, Turkiye Phone: +90 5422639080 E-mail: acikalin@ogu.edu.tr ORCID-ID: orcid.org/0000-0003-1708-467X

Received: 09.01.2021 Accepted: 15.03.2021

Cite this article as: Yılmaz F, Balça Cengiz B, Özen A, Üre İ, Açıkalın MF. Epididymal Leiomyoadenomatoid Tumour: A Rare Case Report and Literature Review. J Urol Surg 2021;8(2):145-148.

๑Copyright 2021 by the Association of Urological Surgery / Journal of Urological Surgery published by Galenos Publishing House. 
nuclei, evident nucleoli and scanty, pale, eosinophilic cytoplasm (Figure 1). Mitotic figures were not observed. Additionally, there were scattered lymphoid aggregates in the stroma. Coagulation necrosis was seen at the centre of the lesion, and there was a hyalinised smooth muscle zone around the necrosis (Figure 2).

On immunohistochemical analysis, the cells in the smooth muscle component were positive for smooth muscle actin and desmin (Figure 3A). Epithelioid cells were positive for cytokeratin AE1/AE3, calretinin (Figure 3B) and Wilms tumour 1 (WT1) and negative for MOC-31, carcinoembryonic antigen, epithelial membrane antigen, prostate-specific antigen, NKX3.1, factor VIII, CD34 and BerEP4. The Ki-67 proliferation index was 3\%. Informed consent was obtained from the patient.

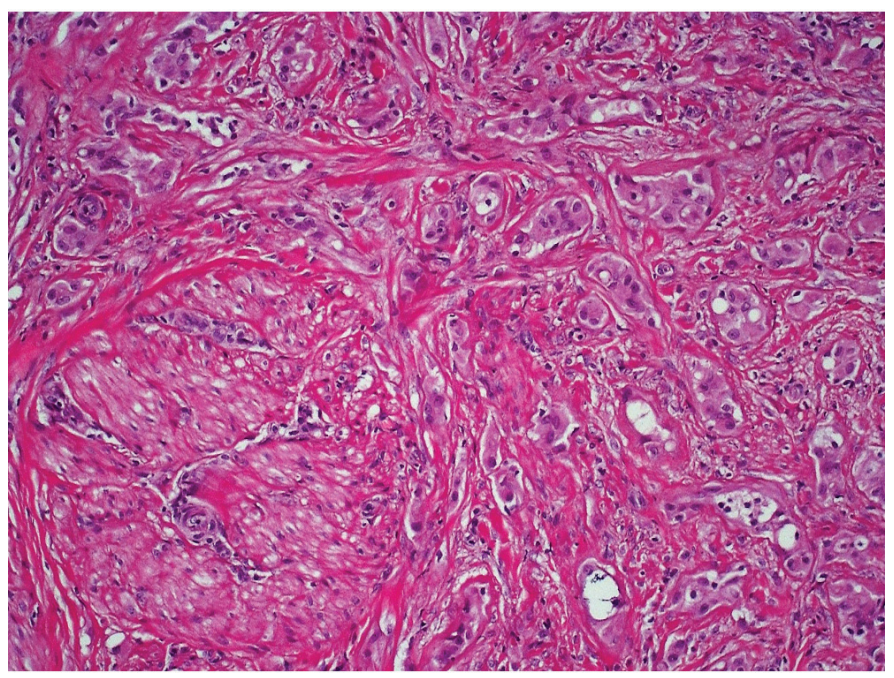

Figure 1. Smooth muscle bundles were separated by tubular structures lined by epithelioid cells with round nuclei and pale eosinophilic cytoplasm (haematoxylin and eosin staining, $\times 200$ )

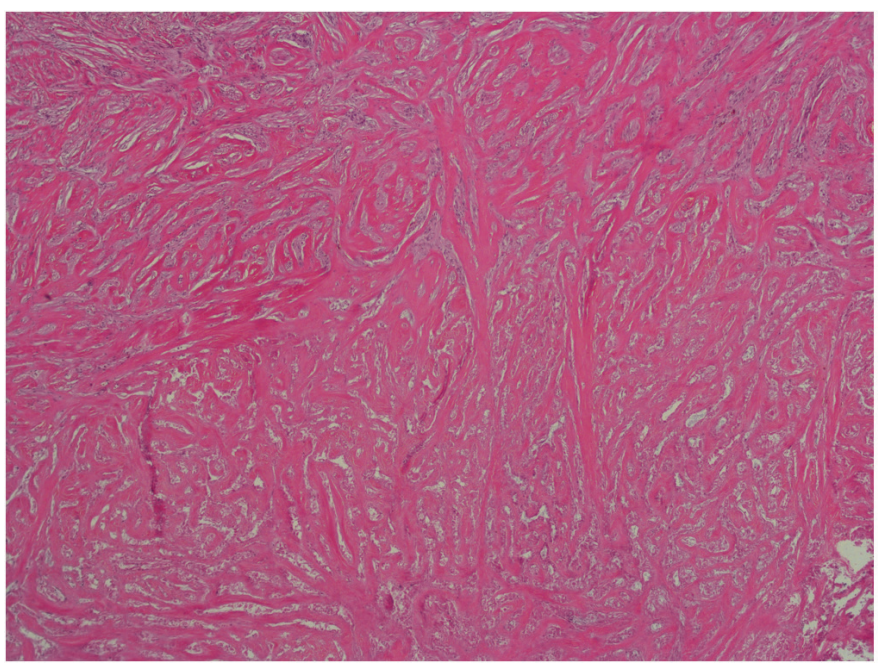

Figure 2. In the lower right corner of the field there was a necrotic region and a hyalinized smooth muscles around it (haematoxylin and eosin staining $\mathrm{x} 100)$

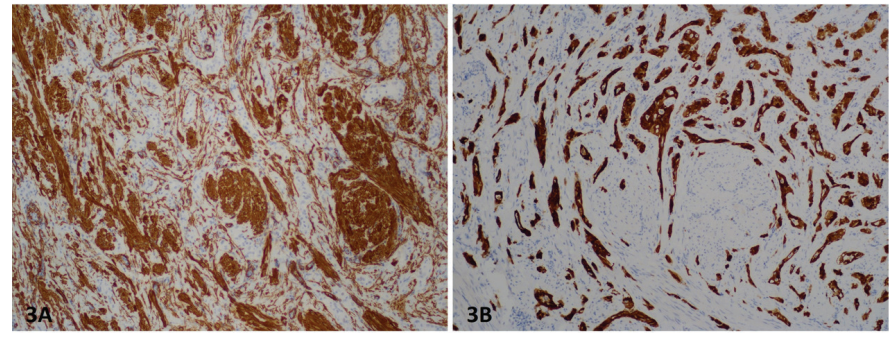

Figure 3A. Smooth muscle component showed expression for smooth muscle actin $(\times 100), 3 B$. The cells lining the tubular structures were positive for calretinin $(x 100)$

\section{Discussion}

ATs are the second most common paratesticular neoplasia after lipoma, accounting for approximately $30 \%$ of all paratesticular neoplasms $(12,13)$. They are the most common epididymal tumour and constitute $70 \%$ of all benign tumours (followed by leiomyoma and papillary cystadenoma, 11\% and $9 \%$, respectively) and 55\% of all epididymal tumours (14). Most patients with AT present with a mass, but some cases are discovered incidentally on imaging studies indicated for other purposes. Epididymal ATs are between 0.4 and $5 \mathrm{~cm}$ in diameter, and most of them arise adjacent to the tail or head of the epididymis. Microscopically, ATs consist of irregular tubules lined with flat and cuboidal epithelioid cells. The stroma is often hyalinised and contains variable amounts of smooth muscle and elastic fibres. Lesions in which the smooth muscle component is prominent are called LAT, which was first used by Epstein in 1992 (2). These lesions have also been reported under different names such as adenomatoid leiomyoma, and adenomatoid tumor with leiomyomatous component $(3,9)$.

To the best of our knowledge, 27 cases of LAT have been reported in the literature. Seventeen of them were located in the uterus or adnexa, and 10 were found in the epididymis. We report an additional case of LAT located in the epididymis. The clinicopathologic features of the cases of epididymal LAT are listed in Table 1.

The lesion diameter of the reported epididymal cases of LAT varied between 1 and $3.5 \mathrm{~cm}$ (mean, $2.25 \mathrm{~cm}$ ), and the ages of the patients ranged from 28 to 76 (mean, 50.9) years. While most of the patients had painless mass (6 cases), some patients complained of pain ( 3 cases). In 6 of 10 patients, the tumour occurred in the tail of the epididymis. No recurrence was observed in any patient. One case exhibited coagulation necrosis, and three cases contained lenfoid aggregates $(3,4,8,9)$. Lesional cells may exhibit mild to moderate cytological atypia (15). In our case, there was coagulation necrosis at the centre of the lesion. The cause of the necrosis was not fully clear. Larger tumour size may be related with necrosis (16), but in 


\begin{tabular}{|c|c|c|c|c|c|c|c|c|}
\hline Authors & $\begin{array}{l}\text { Patient } \\
\text { age } \\
\text { (year) }\end{array}$ & Symptoms & $\begin{array}{l}\text { Lesion } \\
\text { diameter } \\
(\mathrm{cm})\end{array}$ & Laterality & Localisation & $\begin{array}{l}\text { Lenfoid } \\
\text { aggregates }\end{array}$ & Necrosis & Radiological features \\
\hline Hoffmann et al. (5) & 57 & $\begin{array}{l}\text { Painless } \\
\text { lump }\end{array}$ & 2 & Left & $\begin{array}{l}\text { Tail of the } \\
\text { epididymis }\end{array}$ & NM & NM & $\begin{array}{l}\text { US*: Sharply delimited mass } \\
\text { that is more echo-rich than } \\
\text { the testicular parenchyma }\end{array}$ \\
\hline Kausch et al. (6) & 63 & $\begin{array}{l}\text { Painful } \\
\text { mass }\end{array}$ & 3 & Right & $\begin{array}{l}\text { Tail of the } \\
\text { epididymis }\end{array}$ & NM & NM & $\begin{array}{l}\text { US: Combined hypodense } \\
\text { and hyperdense mass } \\
\text { Doppler US: Enhanced } \\
\text { signals of the right rete } \\
\text { testis when compared with } \\
\text { the contralateral testis }\end{array}$ \\
\hline Canpolat (7) & 76 & $\begin{array}{l}\text { Painful } \\
\text { swelling }\end{array}$ & 3.5 & Right & $\begin{array}{l}\text { Tail of the } \\
\text { epididymis }\end{array}$ & NM & - & $\begin{array}{l}\text { US: Lobular mass showing } \\
\text { echogenic areas }\end{array}$ \\
\hline Cazorla et al. (8) & 57 & $\begin{array}{l}\text { Painless } \\
\text { mass }\end{array}$ & 2.5 & Right & $\begin{array}{l}\text { Tail of the } \\
\text { epididymis }\end{array}$ & NM & + & $\begin{array}{l}\text { US: Solid, extra testicular, } \\
\text { well-limited, heterogeneous } \\
\text { and mainly hypoechogenic } \\
\text { mass }\end{array}$ \\
\hline Khan et al. (9) & 39 & Mass & 2.2 & Left & $\begin{array}{l}\text { Tail of the } \\
\text { epididymis }\end{array}$ & + & NM & $\begin{array}{l}\text { US: Extratesticular swelling, } \\
\text { with heterogenous echo } \\
\text { pattern, no fluid and } \\
\text { calcification }\end{array}$ \\
\hline Wazwaz et al. (10) & 33 & $\begin{array}{l}\text { Painless } \\
\text { scrotal } \\
\text { swelling }\end{array}$ & 1.3 & Left & $\begin{array}{l}\text { Tail of the } \\
\text { epididymis }\end{array}$ & NM & - & $\begin{array}{l}\text { US: Well-defined } \\
\text { heterogeneous, } \\
\text { predominantly hypoechoic } \\
\text { lesion with internal } \\
\text { vascularity } \\
\text { Scrotal MRI: Extra testicular } \\
\text { solid mass with very low T2 } \\
\text { signal intensity }\end{array}$ \\
\hline Present case & 59 & $\begin{array}{l}\text { Testicular } \\
\text { pain }\end{array}$ & 1.7 & Right & $\begin{array}{l}\text { Tail of the } \\
\text { epididymis }\end{array}$ & + & + & $\begin{array}{l}\text { Doppler US: Intrascrotal } \\
\text { solid lesion with } \\
\text { microcalcifications } \\
\text { US: Extratesticular and } \\
\text { intrascrotal mass }\end{array}$ \\
\hline
\end{tabular}

our case, the lesion was not large (1.7 cm in diameter). Lymphoid aggregates are commonly present in ATs of the male genital tract. Immunohistochemically, epithelioid cells of LATs are positive for pancytokeratin, CK7 and markers typical of mesothelial origin such as calretinin, podoplanin, WT1 and HBME1. The smooth muscle cell component is positive for smooth muscle actin and desmin.
Microscopic differential diagnoses primarily include leiomyoma, epithelioid haemangioendothelioma, malignant mesothelioma and malignant tumour infiltrating smooth muscle bundles. In some cases, the smooth muscle component may obscure the epithelioid (adenomatoid) component and results in the misdiagnosis of leiomyoma. However, this can be easily 
resolved by detecting the adenomatoid component by careful microscopic examination. For the differential diagnosis with epithelioid haemangioendothelioma, the use of vascular markers such as CD34 and CD31 may lead to correct diagnosis; hence, ATs show negative staining for vascular markers. The presence of coagulation necrosis with associated worrisome regenerative changes can increase diagnostic pitfalls such as malignant neoplastic processes (mesothelioma and invasive carcinomas). In contrast to malignant neoplasms, LATs are usually small and well-circumscribed lesions. Furthermore, the relatively bland cytological features of LATs and the lack of definitive invasion into the adjacent tissues are helpful in this respect. When invasive carcinomas are suspected, immunohistochemical markers could point to the correct interpretation. Other entities to consider in the differential diagnoses include lymphangioma, Sertoli cell tumour, haemangioma and angiosarcoma.

The pathogenesis of LAT remains poorly understood. To date, several hypotheses have been considered on the pathogenesis of these tumours. First, LAT may be a variant of AT. Cazorla et al. (8) suggested that LAT should be considered a variant of AT that originated in precursor cells with dual differentiation, mesothelial and muscle cells. Second, LAT may represent a collision neoplasia consisting of leiomyoma and AT. Third, LAT may be the result of a common AT associated with reactive smooth muscle hyperplasia (17).

To date, none of the reported cases of LAT have shown recurrence or malignant degeneration. Therefore, the surgical removal of the tumour, without orchiectomy, is recommended in cases of epididymal LATs. Orchiectomy is performed only in cases with suspected malignancy. In the present case, inguinal orchiectomy was performed since the mass borders could not be clearly distinguished from the normal testicular tissue.

\section{Conclusion}

LATs are rare benign tumours reported in the epididymis in men and uterus and adnexa in women. Pathologists should be aware of this entity to avoid the undesirable results of the misdiagnosis.

\section{Ethics}

Informed Consent: Written informed consent was obtained from the patient to report this case study and publication of images.

Peer-review: Externally peer-reviewed.

\section{Authorship Contributions}

Concept: F.Y., B.B.C., A.Ö., I.Ü., M.F.A., Design: F.Y., B.B.C., A.Ö., i.Ü., M.F.A., Data Collection or Processing: F.Y., A.Ö., M.F.A., Analysis or Interpretation: F.Y., A.Ö., I.Ü., M.F.A., Literature Search: F.Y., B.B.C., M.F.A., Writing: F.Y., M.F.A.
Conflict of Interest: No conflict of interest was declared by the authors.

Financial Disclosure: The authors declared that this study received no financial support.

\section{References}

1. Wachter DL, Wünsch PH, Hartmann A, Agaimy A. Adenomatoid tumors of the female and male genital tract. A comparative clinicopathologic and immunohistochemical analysis of 47 cases emphasizing their site-specific morphologic diversity. Virchows Arch 2011;458:593-602.

2. Epstein J. Urologic disorders: Differential diagnosis in Pathology. New York, NY: Igasku-Shoin. 1992: s. 173-174.

3. Wilson WW. Adenomatoid leiomyoma of the epididymis. $\mathrm{Br} \mathrm{J}$ Surg 1949;37:240.

4. Romanelli R, Sanna A. Adenomatoid leiomyoma and papillary cystadenoma of the epididymis. Pathologica 1985;77:445-448.

5. Hoffmann JG, Langner C, Rüschoff J, Melchior H. Das adenomatoide Leiomyom des Nebenhodens - ein seltener gutartiger Tumor. Der Urologe B 2000;40:251-254.

6. Kausch I, Galle J, Buttner H, Bohle A, Jocham D. Leiomyo-adenomatoid tumor of the epididymis. J Urol 2002;168:636.

7. Canpolat ET. Leiomyoadenomatoid Tumor of the Epididymis. J Clin Anal Medicine 2013;4:18-20.

8. Cazorla A, Algros MP, Bedgedjian I, Chabannes E, Camparo P, ValmaryDegano S. Epididymal Leiomyoadenomatoid Tumor: A Case Report and Review of Literature. Curr Urol 2014;7:195-198.

9. Khan SH, Mohandas A, Phansalkar M, Kurian SS. Adenomatoid tumour with leiomyomatous component: A rare entity. MedPulse - International Journal of Pathology 2019;9:63-65.

10. Wazwaz B, Murshed $K$, Musa $E_{1}$ Taha N, Akhtar M. Epididymal leiomyoadenomatoid tumor: A case report with literature review. Urol Case Rep 2020;32:101226.

11. Shehabeldin A, Al Sannaa G, El-Zaateri Z, Andino L, Schmolze D, Chapman D, Ayala A, Ro JY. Leiomyoadenomatoid Tumor of Epididymis: A Variant of Adenomatoid Tumor. Ann Clin Lab Sci 2020;50:813-817.

12. Woodward PJ, Schwab CM, Sesterhenn IA. From the archives of the AFIP: extratesticular scrotal masses: radiologic-pathologic correlation. Radiographics 2003;23:215-240.

13. Akbar SA, Sayyed TA, Jafri SZ, Hasteh F, Neill JS. Multimodality imaging of paratesticular neoplasms and their rare mimics. Radiographics 2003;23:1461-1476.

14. Beccia DJ, Krane RJ, Olsson CA. Clinical management of non-testicular intrascrotal tumors. J Urol 1976;116:476-479.

15. Sangoi AR, McKenney JK, Schwartz EJ, Rouse RV, Longacre TA. Adenomatoid tumors of the female and male genital tracts: a clinicopathological and immunohistochemical study of 44 cases. Mod Pathol 2009;22:1228-1235.

16. Skinnider BF, Young RH. Infarcted adenomatoid tumor: a report of five cases of a facet of a benign neoplasm that may cause diagnostic difficulty. Am J Surg Pathol 2004;28:77-83.

17. Quigley JC, Hart WR. Adenomatoid tumors of the uterus. Am J Clin Pathol 1981;76:627-635. 